\title{
SUMINĀJUMS PROFESORAM JĒKABAM ALKSNIM
}

Profesora Jēkaba Alkšña dzimta (Acta Medico - Historica Rigensia). Redaktori: Janīna Danusēviča, Kärlis Eriks Arons un Juris Salaks. Rīgã: Paula Stradina Medicīnas vēstures muzejs, 1999. - 480 lpp.

Apjomīgais, grezni iesietais sējums ar titulu latīṇu valodā satur daudz informācijas par galvenā LU medicīnas fakultātes veidotāja, mūsu ķirurgijijas patriarcha prof. Dr. Med. Jēkaba Alkšna dzīvi, viña amatu, viṇa kollēgām slaveniem Rīgas ārstiem, daudzas interesantas apceres par tautas veselību un citiem medicīniskiem jautājumiem, pat par slimokasēm Latvijas brīvvalsts laikā un jo bagātu foto attēlu klāstu. Saturā, kas veidots sešâs noda|ās, ir apskati par prof. Jēkabu Alksni, viṇa dēlu $D r$. Arvēdu Alksni, viṇa znotu Dr. Aleksandru Mežciemu. Atsevišķa nodaḷa veltīta J. Alkšna meitas Austras Liepiñas pieminai, kas trimdas laikā dzīvoja Anglijā, rosīgi darbojãs latviešu organizācijās un daudz rakstīja trimdas presē. Taču sējums ietver arī apceres par ievērojamiem Rīgas ārstiem, kam ar Dr. J. Alksni nav nekādas radniecības. Tie ir doktori M. K. Veidemanis, E. Apse -Apsītis, J.A. Āboliñ̌s, Kajetāns Jurక̄āns un Ivars Ebels. Tādēl jāatzīst, ka uz apvāka iespiestais virsraksts "Profesora Jēkaba Alkšña dzimta" sedz tikai vienu dalu no sējuma bagâtā satura.

Pirmā noda|a ietver rakstus par Jēkabu Alksni, viña dēlu, znotu, gan arī interesantas paša J. Alkšna "Mūža atminas un atzinas," tāpat pāris viña apceres par latviešu tautas spēku, miesas un gara veselību kā nākotnes pamatu. Autori pieminas rakstiem ir mediḳi Raimonds Pavasars, Ilmārs Lazovskis, Haralds Voskis, Pēteris Stradiṇš un akadēmiķis Jānis Stradiṇš. Dēlu Arvēdu Alksni piemin Arnis Vĩksna, Aleksandru Mežciemu - Juris Salaks un Alfrēds Miltiņ̌s. Pirmā nodạa beidzas ar Jāna Stradina runas transkriptu Rīgas pilsētas 2. slimnīcas jubilejā un Edītes Bērzinas reportāžu par Triju Zvaigžnu ordeñiem Paula Stradiṇa Medicīnas vēstures muzeja krājumā.

Jāna Stradiṇa runa par 2. pilsētas slimnīcu laika griežos atklāj, ka nozīmīga loma slimnīcas attīstībā bijusi gan prof. Alksnim, gan vina toreiz 35 gadus vecajam asistentam Dr. Paulam Stradinam, akadēmiķa Jāna Stradiña tēvam. P. Stradiṇs slimnīcu vada no trīsdesmito gadu sākuma līdz 1947. gadam (ar pārtraukumu hitleriskās Vācijas okupācijas laikā). Runa ietver interesantu P. Stradina piedzīvojumu, sarkanarmijai ienemot Pārdaugavu 1944. gada oktōbrī. LU medicīnas fakultātes dekāns Dr. M. Veidemanis, 
aizbraucot uz Kurzemi, atstāj $\mathrm{Dr}$. P. Stradiṇam dekāna pilnvaras, bet $\mathrm{Dr}$. J. Āboliṇ̌s aizbraucot uz Zviedriju, - slimnīcas direktora pilnvaras. Tā 1944. gada oktobrī, ar personālu uzturoties slimnīcas pagrabā, P. Stradin̄̌s piedzīvo briesmu mirklus. Vācu armijai atkāpjoties, Mārupes ielā aizdedzināta "Lentas" fabrika, un uguns pa Tukuma ielas koka mājāmm draud pārsviesties uz slimnīcu. $\mathrm{Dr}$. Stradiņ̌s organizē cilvēku k̦ēdes ar spaiņiem, lai uguni lokalizētu, kas arī izdodas. Sarkanarmija ienāk Pārdaugavā agrā rītā 15. oktobrī. Kad šāvieni apklust, $D r$. Stradiņš iznāk no pagraba un slimnīcas tuvumā satiekas ar kādu sarkanarmijas vienību. Varam iedomāties, kā Stradiņš, kas 1 pasaules kara laikā bija studējis prestižajā Pēterburgas kara medicinas akadēmijā, toreiz jutās, tuvodamies krievu vienỉbai. Vin̨š sarkanarmiešiem ziņo, ka slimnīcā pretinieka nav, tur tikai medicīniskais personāls, slimnieki, sievietes un bērni. Viñam par lielu pārsteigumu sarkanarmieši pavēl atdot pulksteni un pildspalvu, un tad jauj atgriezties slimnīcā. Dr. Stradiņ̌̌ atgriežas slimnīcā apjucis un nobijies neziṇā par turpmāko...

Arvēds Alksnis 1933. gadā ar izcilību beidzis LU medicīnas fakultāti un vēlāk papildinājies Francijā. Būdams Latvijas aizsargu organizācijā, piedalījies 1934. gada 15. maija apvērsumā. 1944.gada jūlijā viņu iesauc Latviešu legionā, uzticot Legiona lazaretes ķirurg̉iskās noda|as vadību. Lazareti pārce| uz Liepāju, vēlāk uz Vāciju. Šverīnā 1945. gada 2. maijā Alksnis nok|ūst anglu gūstā. Vēlāk līdz 1951. gadam strādāja bēglu slimnīcā Lỉbekā, vadot ḳirurğijas nodạ̣u. Viṇam ir lieli nopelni kaŗa invalīdu ãrstē̌xanā un leǵionāru aprūpē (sk. Latvju Enciklopēdija, 1950-1951., 42. Ipp.). Izcejojis uz ASV, strādājis ārsta profesijā Vašingtonas pavalstī un Kalifornijā. Piedalījies Latviešu ārstu un zobārstu apvienībā, Daugavas Vanagu organizācijā. Apbalvots ar DV organizācijas nozīmi zeltā.

Vēl rosīgāka trimdas organizācijās bijusi viṇa māsa Austra Liepiṇa, kurai veltîta otrā noda|ja. Par Austras dzīves gājumu stâsta viṇas dēls torontietis Valdis Liepiṇš. Par rosīgo darbošanos DV organizācijas vadībã cildinošus vārdus viņai veltĩ Jānis Frišvalds. Atmin̄ās par Austru Liepiṇu vēl dalās Ingrīda Lāckaāja, Zigrîda Daškēvica, Irina Paula, Elfrīda Ezera, Marta Tūtere, Jānis Rapa. Par Austras vīra Edgara Liepiņa kaŗa gaitām, izsūtījumu un vēlāk darbošanos Rīgā, līdz beidzot 1977. gadā izdodas izcelot uz Angliju pie dzīves biedres, stāsta Arturs Boruks, Kārlis Êriks Arons, Aija Dirbe.

Kā jau minēts, sējumā iek|auts bagāts, labas kvalitātes fotoklāsts. Pie katra foto attēla paskaidrojuma latviešu valodā pievienots anglu valodas tulkojums. To veicis Valdis Liepiňšr.

Sējuma bagātais saturs sniedz dzilu ieskatu kādā latviešu tautas vēstures posmā un Latvijas ârstu neatlaidīgajās pūlēs pêc augstākās izglîtíbas. Tas sniedz arī dramatisku liecību par to kā II Pasaules kara laikā frontes līniju un polītisko iekārtu izraisītās pretešḳības izšķir gimenes un to locekliem dažkārt piešḳir trag̉isku mocek|̣ ce|u. Tā ir grămata, ko vêrts lasīt un kurā vērts iedziḷināties.

[Pārpublicēts no rakstu krājuma Jaunā Gaita 2001. 46. gadagājuma, 2.(225.) numura, 57-58. Ipp.] 